\title{
Determination of the Solar Cell Optimal Junction Recombination Velocity Using Hybrid Method
}

\author{
Nzonzolo*, Ibondji Mwaziby Nionsi, Louis Okotaka Ebale, Desire Lilonga-Boyenga \\ Polytechnical Superior National School ENSP, Marien Ngouabi University, Brazzaville, Congo \\ Email address: \\ nzonzolo@umng.cg (Nzonzolo), joeniossy@gmail.com (I. M. Nionsi),dajlouis@yahoo.fr (L. O. Ebale), \\ lilongadesire@yahoo.fr (D. Lilonga-Boyenga) \\ ${ }^{*}$ Corresponding author
}

\section{To cite this article:}

Nzonzolo, Ibondji Mwaziby Nionsi, Louis Okotaka Ebale, Desire Lilonga-Boyenga. Determination of the Solar Cell Optimal Junction Recombination Velocity Using Hybrid Method. Science Journal of Energy Engineering. Vol. 7, No. 3, 2019, pp. 39-44.

doi: $10.11648 /$ j.sjee.20190703.12

Received: September 16, 2019; Accepted: October 15, 2019; Published: October 20, 2019

\begin{abstract}
In this paper we present a technique for determining the optimum junction recombination velocity of a solar cell, using a combination of the electrical equivalent model, and the finite element method. Starting from the continuity equation that describes the solar cell operation solved in one dimension by the finite element method, the excess minority carrier's density is determined. From this density, the photocurrent, the photovoltage and the power produced by the solar cell are determined. The photocurrent and the photovoltage are represented according to the junction recombination velocity, as well as the solar cell power versus the photovoltage, for various values of the series resistance. In considering its equivalent electrical model, the solar cell is modeled and simulated with Matlab/Simulink. In this simulation model, the capacitor initially discharged, charges under the effect of the solar cell. Its impedance varying according to time, represents the load resistance which corresponds to an operating point of the solar cell. During the capacitor charge process for various values of the series resistance, we obtain the current-voltage characteristic of the solar cell in order to highlight the series resistance effects on the solar cell power. From the optimal value of the power, and that of solar cell photovoltage obtained by simulating the solar cell using Matlab/Simulink, the value of the junction recombination velocity corresponding to the maximum value of the solar cell power is determined numerically, for various values of the series resistance.
\end{abstract}

Keywords: Solar Cell, Junction Recombination Velocity, Finite Element, Series Resistance, Photocurrent, Photovoltage, Optimal Power

\section{Introduction}

Since a few decades, several studies are carried out in order to improve solar cells' performances. These studies based for most cases on the analytical methods, permit to highlight the effects of the phenomenological parameters, such as diffusion length, illumination level, junction an back surface recombination velocities, on solar cell electrical parameters [1-4]. Several techniques for solar cells' parameters determination have been elaborate such as ShortCircuit Current Insertion Technique (TICCC) [1, 3], ShortCircuit Current Ratio Technique (TRCCC) $[5,6]$, open Circuit Voltage Curve Insertion Technique (TICTCO) [7].
These techniques based on analytical methods, present some limits in solving some equations. Nowadays one uses more and more numerical methods such as the finite element method, characterized by its robustness and flexibility in its implementation [8-12].

In this paper, we present a technique for determining the optimal junction recombination velocity of a solar cell, based on a method combining the finite element method and the solar cell electrical equivalent model. This approach permits to determine the optimal junction recombination velocity of a solar cell under multispectral steady state Illumination, and highlights series resistance effects on the solar cell power. 


\section{Theoretical Study}

\subsection{Excess Minority Carriers' Density Determination Using Finite Element Method}

Let us consider a solar cell illuminated on its front surface such as shown in figure 1.

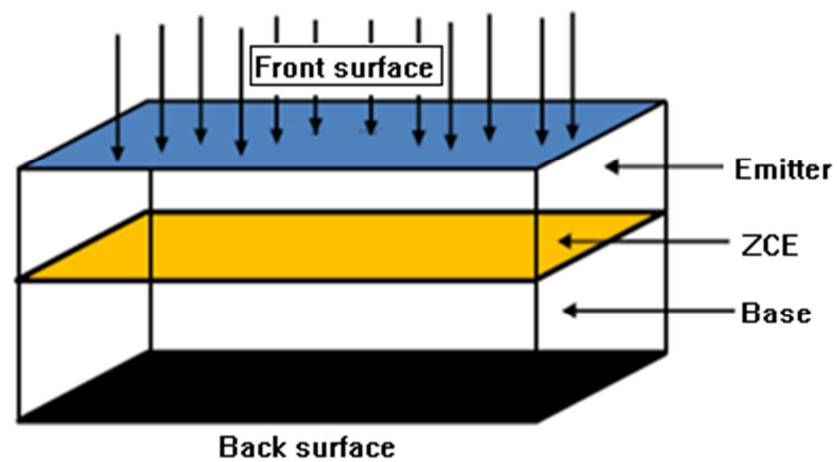

Figure 1. Solar cell illuminated on its front face.

The continuity equation which governs the solar cell operating in considering only excess minority carriers density photogenerated in the base, is a differential equation which may be represented with its boundary conditions as follow [8, $9,13]$

$$
\left\{\begin{array}{c}
-\frac{\partial^{2} \delta(x)}{\partial x^{2}}+\frac{\delta(x)}{L^{2}}=\frac{g(x)}{D} \\
\delta^{\prime}(0)=\frac{S j}{D} \cdot \delta(0) \\
\delta^{\prime}(H)=-\frac{S b}{D} \cdot \delta(H)
\end{array}\right.
$$

$\mathrm{Sj}$ indicates the junction recombination velocity, $\mathrm{Sb}$ the back surface recombination and $\mathrm{H}$, the base depth. $\mathrm{L}$ represents the diffusion length, $\mathrm{D}$, the diffusion coefficient and $g(x)$ the generation rate of carriers' charge. When the solar cell is illuminated by its front surface, the generation rate $\mathrm{g}(\mathrm{x})$ is given by [14-16]:

$$
g(x)=\sum_{1}^{3} n \cdot a_{i} \exp \left(-b_{i} x\right)
$$

$n$ represents the illumination level. The parameters $a_{i}$ and $b_{i}$ are the constants deduced from the modeling of the generation rate considered for the overall solar radiation spectrum $[1,2,3,10] . \mathrm{x}$ indicates the depth in the base such as $\mathrm{x}=0$ at the junction and $\mathrm{x}=\mathrm{H}$ at the back face.

This continuity equation is an elliptic differential equation with Fourier and Neumann boundaries conditions [9-11], and can be written in the following form:

$$
\left\{\begin{array}{c}
-u^{\prime \prime}(x)+c \cdot u(x)=f(x) \\
u^{\prime}(0)=a \cdot u(0) \\
u^{\prime}(H)=b \cdot u(H)
\end{array}\right.
$$

With:

$$
a=\frac{S_{j}}{D} ; b=\frac{S_{b}}{D} ; c=\frac{1}{L^{2}} \text { and } f(x)=\frac{g(x)}{D}
$$

$\mathrm{u}(\mathrm{x})$ is the unknown numerical function to determine by the finite element method.

To solve Equation (3), one assimilates the solar cell base and its depth $\mathrm{H}$, to a domain $[0, \mathrm{H}]$. This domain is subdivided in $\mathrm{N}$ finite elements as represented in figure 2.

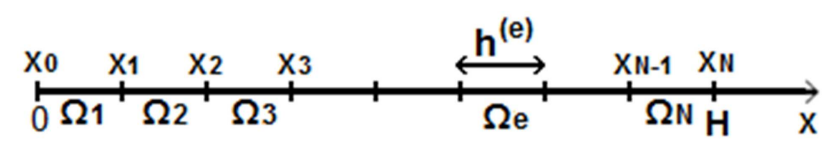

Figure 2. Discretization in finite elements of the solar cell base depth.

Using the Galerkin method to obtain the variational form of the equation (3a), we multiply this equation by a test function $\mathrm{v}(\mathrm{x})$ and integrate over the domain $[0, \mathrm{H}]$. We obtain:

$$
-\int_{0}^{H} \frac{d}{d x}\left(\frac{d}{d x} u(x)\right) v(x) d x+\int_{0}^{H} c(x) u(x) v(x) d x=\int_{0}^{H} f(x) v(x) d x
$$

Integration by part of the first term leads to:

$$
\int_{0}^{H} \frac{d}{d x} u(x) \frac{d}{d x}(v(x)) d x-\left[u^{\prime}(x) v(x)\right]_{0}^{H}+\int_{0}^{H} c(x) u(x) v(x) d x=\int_{0}^{H} f(x) v(x) d x
$$

The equation (5) can be written formally in the following form:

$$
A(u, v)=L(v)
$$

where

$$
A(u, v)=\int_{0}^{H} \frac{d}{d x} u(x) \frac{d}{d x}(v(x)) d x-\left[u^{\prime}(x) v(x)\right]_{0}^{H}+\int_{0}^{H} c(x) u(x) v(x) d x
$$

and

$$
L(v)=\int_{0}^{H} f(x) v(x) d x
$$

After assembly of all the finite elements, the variational form can be written in matric form as:

$$
A_{u} U=L_{u}
$$

The carriers' charge density is given by:

$$
U=A_{u}^{-1} L_{u}
$$




\subsection{Photocurrent Density of and Photovoltage}

The photocurrent density and the phototvoltage are respectively, given by:

$$
J=\left.q D \frac{\partial \delta(x)}{\partial x}\right|_{x=0}
$$

and,

$$
V=V_{T} \ln \left(\frac{N b}{N_{i}^{2}} \delta_{\alpha}(0)+1\right)
$$

with q the elementary charge. $V_{T}=\frac{K T}{q}$ indicates the thermal voltage, $\mathrm{K}$, the Boltzmann constant and $\mathrm{T}$, the absolute temperature.

Knowing the value of the photovoltage, one can determine Iph with the aid of equation (11), value which is used in the equivalent electrical model of the solar cell as represented in figure 3 [2].

\subsection{Solar Cell Modeling}

The electrical equivalent model of the solar cell is depicted in figure 3 with Matlab/Simulink.

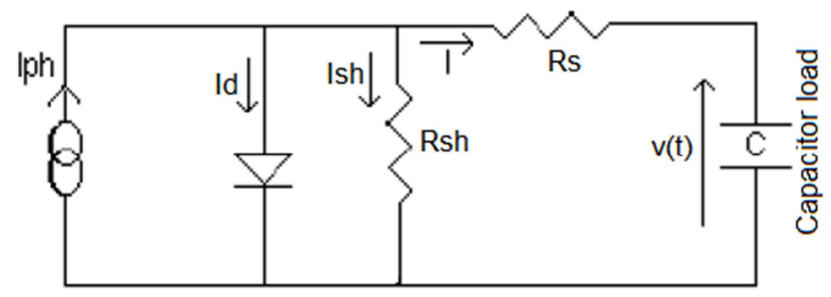

Figure 3. Electrical equivalent model of a solar cell under constant illumination.

As shown in figure 3, this equivalent electrical model contains a current generator Iph, connected in parallel with a perfect diode crossed by a current Id; a shunt resistance Rsh which materializes the loss of current loss by carrier's recombination at the junction; a series resistance Rs due to the voltage drop and ohmic contacts. The capacitor with its capacitance $\mathrm{C}$, represents the load which defines the operating point of the solar cell. It permits to obtain the solar cell current-voltage characteristic [2].

In order to simulate the variation of the solar cell operating point through the current-voltage characteristic, the capacitor initially discharged, with it voltage $\mathrm{v}(\mathrm{t})=0$, charges under the effect of the solar cell. Its impedance varying according to time, represents the load resistance, which corresponds to an operating point of the solar cell.

Thus at the initial moment, the capacitor is discharged this case corresponds to a short-circuit operation. When it is completely charged, the current is equal to zero and that corresponds to an operation in open circuit of the solar cell. Like this, during the charging process of the capacitor, the solar cell operating point scans the current-voltage characteristic from the short-circuit operating point to the open circuit operating point [2].

The elements contained in the electrical equivalent model of the solar cell, are thus modeled and simulated using the Matlab/Simulink software to obtain the maximum power which permits to determine the optimal junction recombination velocity.

For the simulation with Matlab/Simulink, the current generator Iph is modelled by a constant current generator.

Assembly in Matlab/Simulink of all these elements of the electrical equivalent model of the solar cell leads to a simulation model of the solar cell under constant illumination, represented in figure 4.

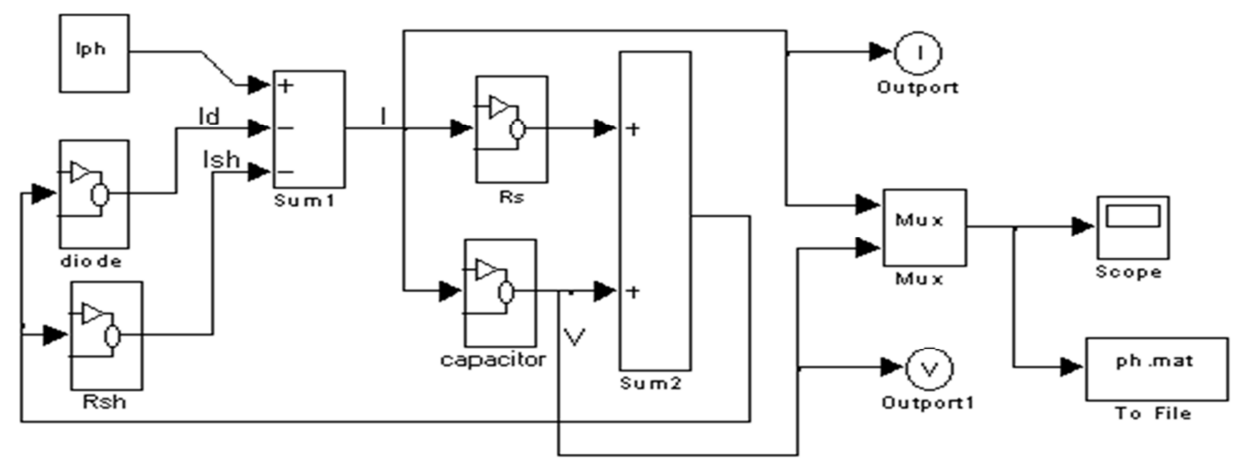

Figure 4. Simulation model of the solar cell under constant illumination.

In addition to the elements modeled above, this simulation model contains two outputs namely outport and outportl which permit to collect the current I and the voltage $\mathrm{V}$ respectively.

\section{Results and Discussions}

\subsection{Determination of the Photovoltage Versus the Junction Recombination Velocity}

From the numerical codes conceived with Matlab using the finite element method, we have determined numerically, the photovoltage according to the junction recombination velocity, after assembling the matrix $\mathrm{Au}$ and $\mathrm{Lu}$, where only the base contribution is taken into account. After studying the convergence of these numerical solutions, we have obtained the photovoltage according to the junction recombination velocity $\mathrm{Sj}$, as represented in figure 5 .

This curve is used as abacus to determine graphically, the optimal junction recombination velocity of the solar cell. 


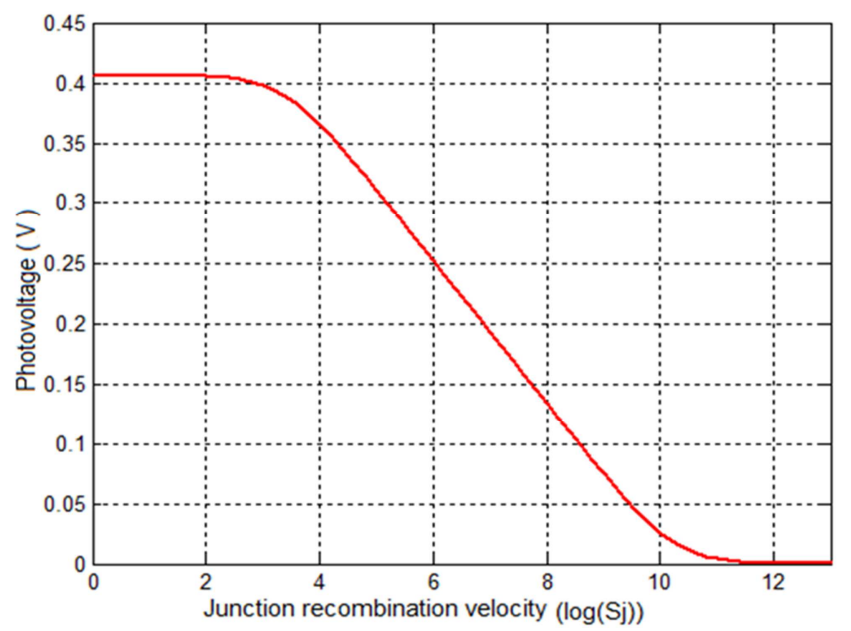

Figure 5. Photovoltage versus junction recombination velocity: Sj, $D=26 \mathrm{~cm}^{2} / \mathrm{s} ; L=0,01 \mathrm{~cm}, S b=10^{3} \mathrm{~cm} / \mathrm{s}$.

As shown in this figure, for low values of the junction recombination velocity $\mathrm{Sj}$, the photovoltage is constant and corresponds to the open circuit photovoltage. Then it decreases until to cancel each other out when the short-circuit operation is reached.

\subsection{Photocurrent and Photovoltage}

The simulation model described above in figure 4 allows us to obtain values of the photovoltage and the photocurrent delivered by the solar cell, during the capacitor charging process. Thus we have represented the photocurrent and the photovoltage delivered by the solar cell, with a value of series resistance $R_{s}=0$, in figures 6 and 7 respectively.

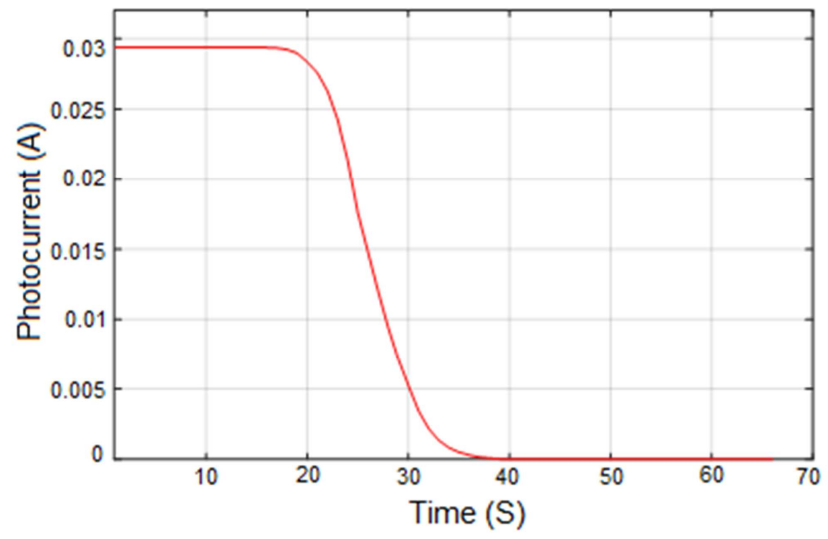

Figure 6. Photocurrent

We can note that for the low values of time between 0 and $15 \mathrm{~s}$ approximately, the photocurrent through the capacitor is constant and close to $30 \mathrm{~mA}$. Then it decreases and is cancel each other out around $40 \mathrm{~mA}$ when the capacitor is completely charged.

The photovoltage is also represented in figure 7 below.

It is noted that, the photovoltage increases according to time and reaches a constant value corresponding to the open circuit photovoltage $\mathrm{Vco}$ around $0,6 \mathrm{~V}$ at the end of a time $\mathrm{t}$ close to $30 \mathrm{~s}$.

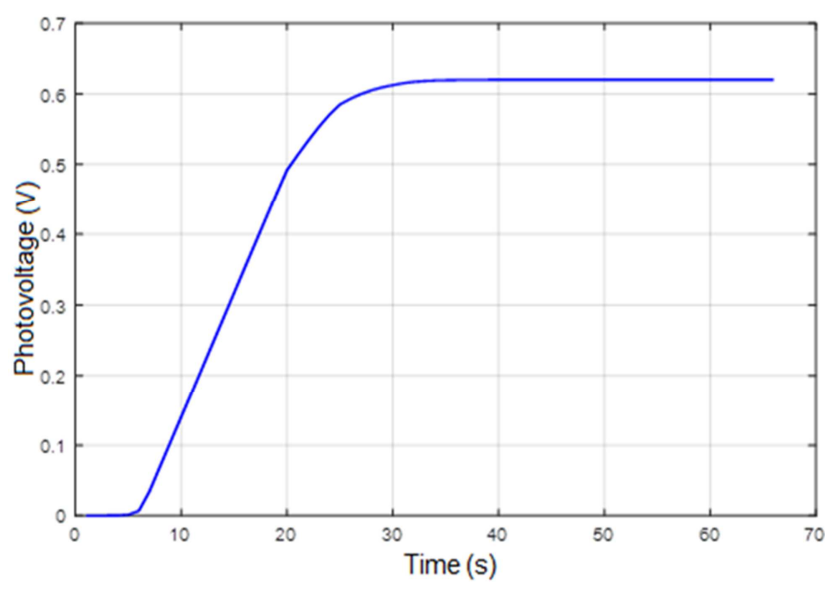

Figure 7. Photovoltage.

\subsection{Caractéristique Courant-tension}

Given at each time step we have a value of the photocurrent and a value of photovoltage corresponding to the solar cell operating point during capacitor charge process, one can obtain the current-voltage characteristic of the solar cell.

Thus, for various values of series resistance Rs, the current-voltage characteristic and the power produced by the solar cell, are represented respectively in figures 8 and 9 .

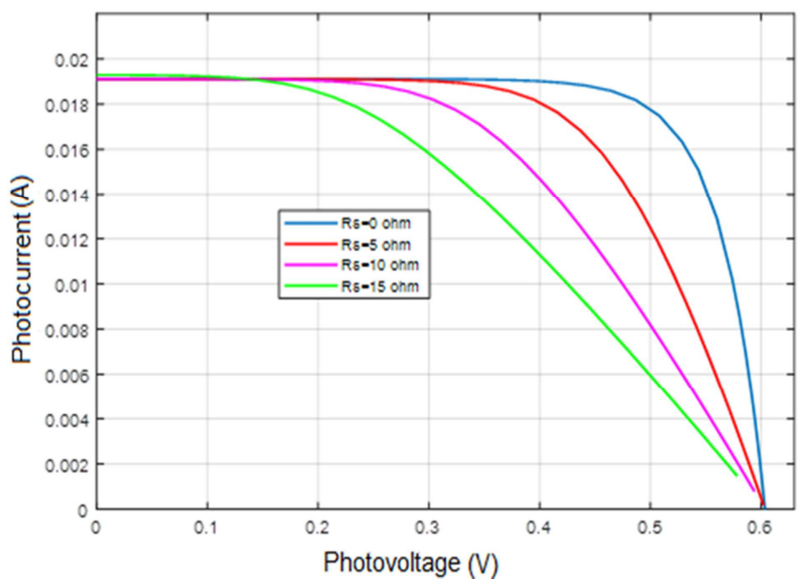

Figure 8. current-voltage characteristic for various values of the series résistance.

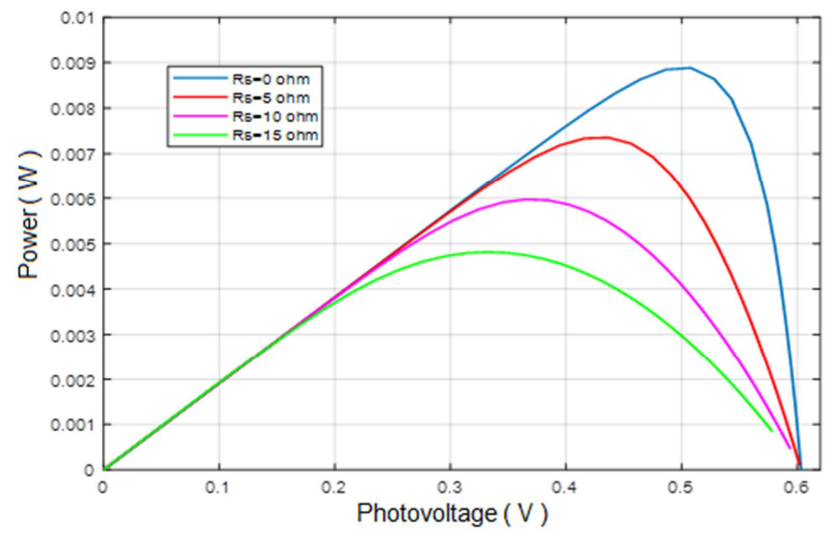

Figure 9. Power versus photovoltage for various values of $R$ s. 
As waited, one can to note that the series resistance Rs has an effect on the current-voltage characteristic of solar cell, which is revealed by the reduction of the fill factor, when Rs increases. This effect is also noticed on the power of the solar cell represented below, for various values of the series resistance.

The curves of figure 9 present a maximum when the photovoltage increases. This maximum power corresponds to an optimal junction recombination velocity Sjop, associated to the optimal operation of the solar cell [2].

\subsection{Determination of the Optimal Junction Recombination Velocity}

From the electrical equivalent model of the solar cell and for various values of Rs, one determines the maximum power Pmax delivered by the solar cell, the open circuit photovoltage Vco and the photovoltage Vopt corresponding to Pmax. Given that the solar cell is represented by a current generator, the short-circuit photocurrent Iph is known. In the numerical computer code of the finite elements model, one gives to Vco, and Iph the values determined from the Simulink model. The optimal junction recombination velocity Sjop is thus numerically obtained.

The results obtained are shown in the following table:

Table 1. Table of numerical values of the optimal junction recombination velocity.

\begin{tabular}{lllll}
\hline Rs $(\mathbf{\Omega})$ & $\mathbf{0}$ & $\mathbf{5}$ & $\mathbf{1 0}$ & $\mathbf{1 5}$ \\
\hline Pmax $(\mathrm{mW})$ & 8.90 & 7.40 & 6.00 & 4.80 \\
Vopt $(\mathrm{V})$ & 0.507 & 0.436 & 0.385 & 0.335 \\
Sjop $(\mathrm{cm} / \mathrm{s})$ & $2.52 \cdot 10^{4}$ & $1.58 \cdot 10^{5}$ & $6.30 \cdot 10^{5}$ & $2.51 \cdot 10^{6}$ \\
\hline
\end{tabular}

As expected, these results show that series resistance has an effect on the power and the optimal point operating point of the solar cell. The higher it is, the more the junction recombination velocity Sjop corresponding to the maximum power is great. That can be explained on the one hand, by the fact that the junction recombination velocity being composed of two components [2, 6, 7] namely the intrinsic junction recombination velocity Sjo, and the recombination velocity $\mathrm{SF}$, and on the other hand, by the increase in Rs revealing the deterioration of the quality of material; the increase in Rs causes the increase in the ohmic losses and thus the increase in Sjo. Losses being enormous, the power delivered by the solar cell decreases and the optimum power is obtained with great values of the junction of recombination velocity $\mathrm{Sj}$.

\section{Conclusion}

In this study we presented a method allowing to determine the optimal junction recombination velocity of a solar cell. by highlighting the series resistance effects on the junction recombination velocity.

After solving the continuity equation using finite element method. a numerical solution of the photogenered carriers' charge density has been obtained. This carriers' charge density has served to determine the photocurrent and the photovoltage according to the junction recombination velocity $\mathrm{Sj}$. Knowing the maximum value of the power produced by the solar cell. the short-circuit photocurrent. open circuit photovoltage obtained starting from the electrical equivalent model of the solar cell, and adapted to the theoretical numerical values. the optimal junction recombination has been determined.

These results being in accordance with those obtained previously by the other authors, this study based on numerical simulations. Can continue by analyzing the effects of other parameters like shunt resistance. and by making experimental measures.

\section{References}

[1] Nzonzolo, Lilonga-Boyenga D. Sissoko G. 2014, Illumination level effects on microscopic and macroscopic parameters of a bifacial solar cell. Energy and Power Engineering, 6, pp. 2536, 2014.

[2] Nzonzolo. Détermination des paramètres de recombinaison à partir de l'étude de la caractéristique courant-tension d'une photopile bifaciale sous éclairement constant. Thèse de Doctorat 3eme cycle. Université Cheikh Anta Diop. Dakar. Sénégal, 2004.

[3] Nanema E. Modélisation d'une photopile bifaciale au silicium: Méthodes de détermination des paramètres des paramètres de recombinaison: Thèse de Doctorat troisième cycle. Université Cheikh Anta Diop. Dakar Sénégal 1996.

[4] Ould El Moujtaba M. A. Ndiaye M. Diao A. Thiame M. Barro I. F. and Sissoko G. Theorical study of the Influence of Irradiation on Solar Cell Under Multispectral Illumination. Research Journal of applied Sciences Engineering and Technology 4 (23) pp. 5068-5073, 2012.

[5] Sayad Y., Détermination de la longueur de diffusion des porteurs de charge minoritaires dans le silicium cristallin par interaction lumière matière. Thèse de doctorat. Institut National des Sciences Appliquées de Lyon. 2009. France.

[6] Ly I., Lemrabott O. H. Dieng B. Gaye I. Gueye S. Diouf M. S. and Sissoko G.. 2012. Techniques de détermination des paramètres de recombinaison et le domaine de leur validité d'une photopile bifaciale au silicium polycristallin sous éclairement multi spectral constant en régime statique. Revue des Energies Renouvelables Vol. 15. ํ2 187-206.

[7] Mohammad S. N. An Alternative Method for the Performance Analysis of Silicon Solar Cells. J. Appl. Phys. 61 (2). pp. 767$772,1987$.

[8] Nzonzolo. Contribution à la Caractérisation d'une Photopile Poly cristalline au Silicium par la Méthode des Eléments Finis. Thèse de doctorat unique. Université Marien NGOUABI. ENSP, Brazzaville Congo. 2017.

[9] Nzonzolo, Desire Lilonga-Boyenga. Camille N. Mabika and Gregoire Sissoko. Characterization of a Bifacial Silicon Solar Cell Under Multispectral Steady State Illumination Using Finite Element Method. Progress In Electromagnetics Research M. Vol. 53. Pp. 131-140, 2017.

[10] Nzonzolo. Désiré Lilonga-Boyenga. Camille Nziengui Mabika. Grégoire Sissoko. Two-Dimensional Finite Element Method Analysis Effect of the Recombination Velocity at the Grain Boundaries on the Characteristics of a Polycrystalline Silicon Solar Cell. Circuits and Systems. 7. Pp. 4186-4200, 2016. 
[11] Daveau Christian. cours methodes des elements finis 2010/2011: Universite de Cergy-Pontoise. Departement de mathematique. 95302. Cergy-Pontoise. cedex France.

[12] Matthew N. O. Sadiku. 2001. Numerical Techniques in Electromagnetics (Second Edition) CRC Press LLC. Boca Raton London. New York. Washington. D. C.

[13] Dione M. M., Ly I., Diao A., Gueye S., Gueye A., Thiame M., Sissoko G., Determination Of The Impact Of The Grain Size And The Recombination Velocity At Grain Boundary On The Values Of The Electrical Parameters Of A Bifacial Polycristallin Silicon Solar Cell, Engineering Science and Technology: An International Journal (ESTIJ), Vol. 3, No. 1, P. 66-73, 2013.

[14] Gueye S., Ly Diallo H., Ndiaye M., Dione M. M., Sissoko G., 2013, Effect of the Boundary Recombination Velocity and the
Grain Size at the Phenomenological Parameters of the Monofacial Solar Cells under Multispectral Illumination in Steady State, International Journal of Emerging Technology and Advanced Engineering, Volume 3, Issue 12, P. 1-8, 2013.

[15] Matar Gueye, Hawa Ly Diallo1, Attoumane Kosso Mamadou Moustapha, Youssou Traore, Ibrahima Diatta, Gregoire Sissoko: Ac Recombination Velocity in a Lamella Silicon Solar Cell, World Journal of Condensed Matter Physics, 8, 185-196, 2018.

[16] Mint Sidihanena Selma, Ibrahima Diatta, Youssou Traore, Marce Sitor Diouf, Lemrabottould Habiboulahh, Mamadou Wade, Grégoire Sissoko: Diffusion capacitance in a silicon solar cell under frequency modulated illumination: Magnetic field and temperature effects, Journal of Scientific and Engineering Research, 5 (7): 317-324, 2018. 